\title{
PARTNERSHIP MANAGEMENT BETWEEN VOCATIONAL SCHOOLS WITH THE WORLD OF BUSINESS AND INDUSTRY TO IMPROVE THE QUALITY OF GRADUATES WHO ARE READY TO WORK
}

(Case Study at SMK Negeri 1 Losarang and SMK Negeri 1 Gantar in Indramayu Regency-West Java)

\author{
Siti Ubaidah \\ SMK Negeri Kabupaten Indramayu \\ Email: umiubayyyy@gmail.com \\ Sutaryat Trisnamansyah \\ Universitas Islam Nusantara (UNINUS) \\ Emai : yatsutaryat@ymail.com \\ Husen Saeful Insan \\ Universitas Islam Nusantara (UNINUS) \\ Email: huseninsan@gmail.com \\ Naungan Harahap \\ Universitas Islam Nusantara (UNINUS) \\ Email: naungan@gmail.com
}

\begin{abstract}
The management of the partnership between State Vocational High Schools (SMKN) and the World of Business and Industry (DUDI) has not been running optimally in its implementation, so that many partnership programs have not been realized properly. If there is no solution, it is feared that partnership activities will not work. This research aims to: To determine the planning, organization, implementation, assessment of problems and partnership solutions. The philosophical foundation of this research is progressivism philosophy, while the theoretical basis used is management theory, partnership theory and graduate quality theory. The research approach used is a qualitative approach. Data collection was carried out through: documentation study, observation and interviews, triangulation. The results showed that: (a) The planning was made together with the school committee, the principal of the vocational school, the wakasek in the field of public relations / industry, the head of light vehicle engineering, and the teacher sat with the DUDI in this case PT Teja Berlian Mitsubshi and PT Suzuki Putra Damai Bahagia, so that cooperation program agreement with DUDI; (b) Organizing by forming a team in charge of relations with DUDI and having its own main duties and functions. (c) Implementation requires cooperation with PT Teja Berlian Mitshubisi and PT Suzuki Putra Damai Bahagia, in order to improve the quality of graduates, as expected by DUDI. The implementation of the partnership program consists of: internship, production unit, competency test, teacher internship, (d) assessment of learning outcomes, internship, competency package testing and competency certification. and skills aspects (e). The problems in the partnership are: human resources managing the partnership, budget, infrastructure, the number of DUDI that is not comparable with SMK graduates and the demands of the industrial world; (f) Partnership solutions with innovation and changes in human resource management, budgets and infrastructure, the government's efforts to develop a teaching factory curriculum through partnerships, and schools to prepare students to have superior competencies, be creative, innovative, understand the digital world (IPTEK). Conclusion; There is a common goal of the partnership between SMK and DUDI, namely; improving quality according to market needs, synchronizing curriculum and synergizing school programs, increasing the absorption and placement of school graduates into the world of work. Collaboration between SMK and DUDI has an impact on improving the quality of SMK graduates, both in terms of input, process, output and outcome. Recommendations: (1) For SMK it can be used as a basis for cooperating partnerships with DUDI; (2) For DUDI it can be used as a basis for
\end{abstract}


collaborating with SMKs; (3) For students it is used as a basis for increasing their competence; (4) For Researchers, can be used as a basis for further research on the Management of SMK partnerships with DUDI, to improve the quality of graduates who are ready to work in Indramayu Regency.

Keywords: Management, Partnerships, Quality of Graduates Who Are Ready to Work.

\section{A. INTRODUCTION}

In facing the globalization era, competition is very fierce in various sectors of life, bringing two possibilities, namely opening up opportunities and increasing competition, especially in the labor sector. The available job opportunities are not proportional to the number of job seekers, which results in very tight competition, therefore increasing entrepreneurial competence and ability is an alternative to overcome this competition. The magnitude of the unemployment rate is due to the fact that the number of labor force continues to increase from year to year and is not matched by the availability of employment opportunities. So that the number of unemployed people increases, especially among adolescents, this is in accordance with the results of a survey by the Central Statistics Agency as follows: The number of unemployed people in Indonesia as of February 2016 is 7.02 million people, reduced by 430,000 people compared to the position in February 2015. Most unemployed are graduates of Vocational High Schools (SMK) ). In February 2016, the highest open unemployment rate was at the SMK education level at $9.84 \%$. This figure is an increase of $0.79 \%$ compared to February 2015. Through this data, continued Suryamin, it can be interpreted that for every 100 workforce graduates of SMK, there are around 9 to 10 people who are still unemployed. The lowest open unemployment rate is in elementary school education and below with a figure of $3.44 \%$ of the total workforce. The following is a breakdown of the open unemployment rates, namely SD and below $3.44 \%$, SMP 5.76\%, SMA 6.95\%, and SMK 9.84\% (Jefriando, 2016).

One of the school education channels that is used as an alternative to overcome unemployment is vocational education. According to (Walter in Kuswana, 2013: 157) vocational education is an educational program that prepares people to enter the world of work, both formal and non-formal. This understanding indicates that the output to be achieved from the education process in Vocational High Schools (SMK) is a graduate who has a certain skill level so that they are ready to enter the world of work. Based on UUSPN 20 of 2003 Article 15 paragraph 2 states that vocational education is secondary education that prepares learning participants, especially to work in certain fields.

Therefore, the curriculum applied in vocational schools is designed differently from that applied to public high schools. Because it is focused on training students with certain occupational skills, the teaching material for the learning system in vocational schools is more emphasized on practical matters or the majority related to psychomotor aspects. Besides that, aspects of knowledge, aspects of attitude and aspects of skills are able to turn challenges into opportunities and limitations to trigger success.

To achieve success, quality education is needed at Vocational High Schools (SMK), requires learning materials and good governance (good governance system). The learning material provided is full of benefits, insights, experiences, and is able to change attitudes, thoughts and behavior. Meanwhile, good governance can be obtained by meeting comprehensive management and governance standards, linkages between functions and components, is measurable and sustainable and implemented through a good system by clean and professional managers. This is an important task in the world of education, to realize quality education, this is in line with the opinion of Mulyasana (2011: 120), that: Quality education is education that is able to carry out the process of maturing the quality of students developed by freeing students from ignorance, incapacity, helplessness, dishonesty, and from bad morals and faith. Quality education is born from a good planning system and a good governance 
system and is delivered by good teachers with a quality education component, especially teachers (Mulyasana, 2011. p.120).

In connection with the quality education concept above, to realize quality education in a Vocational High School (SMK), requires good planning (good planning system) in various learning activities. Whether held within the school itself or during learning in the business world and industry through partnerships. Then able to meet the competency standards of graduates and be able to print graduates ready to enter life at this time and in the future. So that vocational high school graduates have religious spiritual strength and various skills or competencies needed by themselves and society. In the teaching and learning process, teachers play an active role in supporting the partnership program at vocational education institutions (SMK) with the Business and Industry World (DUDI). Teachers should adapt their learning resources to the Business and Industry World (DUDI) so that they are relevant to the needs of various local, national and international sectors.

An important step in a partnership in accordance with the understanding of this understanding shows that the relationship that is built is developed to jointly support and develop a form of vocational school work that specifically improves skills in accordance with the basis of the scientific discipline developed shows that the value of understanding the scope that must be built in understanding the value of the partnership is understand and understand the values of work which are the basis for the implementation of work itself.

Providing mutual benefits for all partner institutions, by working together and complementing each other so that the effectiveness of education runs smoothly. Relating to human relations with the interests of stakeholders, which is based on a balance of power.

In implementing partnerships between the business world and the industrial world with vocational schools, many partnership activities that can be developed by this program, including: (a). Management of joint activity programs between education providers and partner institutions. (b). Utilization of infrastructure owned by partner institutions. (c). Funding program in order to realize a program that will be implemented. (d) Utilization / placement of graduates from educational institutions to the work sector or commodities required by partner institutions.

According to Kuncoro school partnerships with other institutions in society aim to (Mudrajad, 2010. p.4):

a) Assisting schools in carrying out educational tasks.

b) Enrich learning experiences obtained by students in various life settings.

c) Bringing student learning activities closer to the real context in everyday life.

d) Helping schools to take advantage of the resources available in the community for educational activities.

e) Increase the development of independence, creativity, tolerance and openness of students in learning life.

f) Increase the meaning of student learning activities for life change and solving social problems.

The partnership between vocational schools with the business world and industry in the provision of education can further encourage educational activities to be more efficient and effective, so that the realization of the objectives of the partnership can run well.

Meanwhile, the partnership itself has various meanings. The essence of this opinion is that partnership has a variety of meanings, with the variety that is owned by the term partnership, which will increase the understanding and clarity of the term, this is in line with Lendrum's opinion quoted by Rukmana, that; The partnership will provide benefits to all partner institutions through collaboration, so the various 
sources available at each partner institution will complement each other so that the effectiveness in delivering education (Rukmana, 2006. p. 158).

From the explanation above it can be taken the meaning that indicators of educational success can be assessed from the quality of inputs, processes and products, where the overall quality is strongly influenced by the partnership behavior of each educational institution / institution that partners in the development of expertise / study programs, curriculum development, establish learning technology to create an atmosphere in the learning process, establish evaluation criteria and the quality of the success of students. The implementation of educational partnerships will be effective, as shown by the success in achieving the indicators that have been determined in the policies for collaborating, such as improving the quality of learning, the quality of student success, the harmony and relevance of the curriculum to the world of work and the increased absorption rate of graduates in the workforce

\section{B. METODE}

The research method uses a qualitative descriptive method, which describes all the symptoms and facts in the field and links and analyzes all the symptoms and facts with the problems that exist in the research and then adjusts them to the conditions that occur in the field. Descriptive research method is a method that aims to make systematic, factual, and accurate descriptions of the facts and characteristics of a particular population or area. Data source :

a. Research locations: Vocational High School 1 Losarang and 1 Gantar Vocational High School in Indramayu Regency.

b. Research Subject: The research subject is a source that can provide information on the problem researched by the author. (1). Supervisor, from the two Vocational High Schools studied; (2). Principal, (3). Vice Mayor Hubin, (4). Head of study program or head of competency and teachers, (5). Business world and industrial world.

To obtain data, 3 techniques were used, namely:

a. Observations or observations that use a structured non-participant observation type in which the researcher has formulated guidelines for limiting the focus and sub-focus of the study. The purpose of observations made by researchers by making observations is to obtain data about how the partnership was carried out at SMKN Losarang and SMKN Gantar.

b. In-depth interviews (in depth interviews). With in-depth interviews, detail is the researcher's effort in finding information experiences from the topic being studied, namely about the Partnership Management between Vocational Schools and the business world and industry to improve the quality of graduates who are ready to work. The informant is (1) Supervisor, from the two Vocational High Schools studied; (2). Principal, (3). Vice Mayor Hubin, (4). Head of study program or head of competency and teachers, (5). Business world and industrial world.

c. Documentation by examining archives and records. By utilizing secondary data in the field, it is obtained through facts stored in the form of letters, daily notes, photo archives, meeting results, souvenirs, activity journals, MoU documents and others.

Data analysis consists of testing, categorizing, tabulating, or recombining evidence to show the initial proposition of a study (Yin, 2011. p.133). The data analysis uses an interactive pattern which includes three components of the analysis, namely; the orientation stage, the exploration stage, and the member check stage.

To ensure data validity, data validity tests were carried out which included: credibility, transferability, dependability, and confirmability (Moleong, 2001. p. 324). Of the four data validity tests, the researcher used the credibility test through data triangulation, by combining data from one source with another from a combination of documentary data, in-depth interviews and observations.. 


\section{RESULT AND DISCUSSION}

Based on the findings that the partnership between SMK and DUDI begins with planning, organizing, implementing, and evaluating, in determining the various aspects that will be carried out, this is in line with the opinion of GR Terry that: Management is a unique process, which consists of planning, organizing, mobilizing and controlling actions, which are carried out to determine and achieve predetermined targets through the use of human resources and other sources (Terry, 2010. p.16).

The basic concept to be implemented in a partnership between SMK and DUDI is to improve the quality of graduates who are ready to work. This collaboration includes six things, namely: (1). Planning in partnership between vocational high schools and the world of business and industry to improve the quality of graduates who are ready to work; (2). Organizing in partnership between vocational high schools and the world of business and industry to improve the quality of graduates who are ready to work; (3). Implementation in a partnership between vocational high schools and the Business and Industry to improve the quality of graduates who are ready to work; (4). Assessment in a partnership between vocational high schools and the world of business and industry to improve the quality of graduates who are ready to work; (5). Problems in the partnership between vocational high schools and the world of business and industry to improve the quality of graduates who are ready to work; (6). Solutions in partnership between vocational high schools and the world of business and industry to improve the quality of graduates who are ready to work, among others;

\section{Partnership Planning Between SMK and DUDI}

Partnership planning is carried out according to the partnership implementation schedule procedure must at least refer to the SOP (Standard Operating Procedure) on the DUDI side. The procedure for implementing the internship is carried out by DUDI, including: 1) Inviting DUDI to discuss the apprenticeship program. 2). Creating a cooperation script (Mou). 3). Signing of the cooperation document (Mou) with DUDI. 4). Implement the provisions contained in the cooperation script (Mou). Submit to DUDI regarding the start of the internship schedule (the number of internship students and time is adjusted to the needs of the DUDI company / party).

The results of the collaboration between educational institutions and the business / industrial world (DUDI) can be seen from the quality objectives that have been implemented with the business / industrial world (DUDI). Both those who have partnered and those who have not partnered with educational institutions, the World of Business and Industry (DUDI), have provided opportunities for industrial work practices (Prakerin). Vocational education institutions, especially the Light Vehicle Engineering (TKR) expertise program, all have a mutual agreement (MoU) with PT. Teja Berlian Mitshubisi and PT. Suzuki Loves Peace, Happy Son.

\section{Organizing Partnerships between SMK and DUDI}

Organizing partnerships that are carried out in partnership activities of Vocational High Schools (SMK) with the World of Business and Industry (DUDI) is by forming a team in charge of relations with the industrial world and having their own main duties and functions. This is done so that management can work professionally and avoid concurrent positions. The principal together with the deputy head, especially the curriculum and public relations / industrial relations form the internship team and the BKK team. This team collaborates with departments in Vocational High Schools (SMK) with DUDI for smooth and successful collaboration. These results are supported by interviews with school principals as follows: Organizing partnerships between Vocational High Schools (SMK) and DUDI is carried out by 
the school principal as chairman then Deputy Head of Public Relations and Industry and chairman of the Light Vehicle Engineering competency program (TKR) at Vocational High Schools (SMK) Furthermore, this is done by forming a working group and an internship team and BKK. This team collaborates with divisions for the smooth running and implementation of collaboration between Vocational High Schools (SMK) and DUDI in a professional manner to be able to produce productive graduates.

\section{Implementation of Partnerships between Vocational Schools and DUDI}

Implementation of partnerships between SMKN and DUDI, consisting of; from internships / street vendors, production units, competency tests, recruitment, teacher apprenticeships, in the implementation of the partnership program briefing, coaching and granting of authority are in accordance with the structure of tasks within the organization that has been described. Each program and expertise has detailed tasks that have been set as standards in carrying out daily tasks and are supervised by the head of the program and their respective fields. From the results of the interview, it was revealed that the planning of partnership program activities at State Vocational High Schools (SMK) was guided by the policies of the Principal, referring to the Strategic Plan (RENSTRA) and School Operational Plans which lead to efforts to improve quality. Therefore, it is necessary to collaborate with PT Teja Berlian Mitshubisi and PT Suzuki Cinta Damai Putra Bahagia in order to improve the quality of graduates so that they have a number of competencies as expected by the business world and / or the industrial world. The partnership program consists of: Industrial work practices (Prakerin), production units, competency tests (National Expertise Competency Examinations), teacher internships. recruitment, practical tools and resource person assistance.

In implementing the partnership program between Vocational High Schools (SMK) and the Business and Industry (DUDI), to improve the quality of graduates who are ready to work, this cannot be separated from the program of the Directorate of Vocational Secondary Education since 2000 running industrial work practice programs (Prakerin) abroad. . The results obtained from industrial practices in overseas companies in recent years are starting to show positive results. Many Vocational High School (SMK) students gain valuable experience, so that after graduating there are companies that are ready to recruit Vocational High School (SMK) graduates. Internship is an effective means for students to practice knowledge and skills according to the competencies they already have. Of course, to send apprenticeship students abroad must be accompanied by the preparation and improvement of the work ethic of students, the quality of the learning process and even the ability to speak English and other foreign languages need to be intensified so that students are ready to face the demands of the world of work abroad.

Meanwhile, the growth of the domestic industry is no longer significant with the number of Vocational High School (SMK) graduates each year. Industrial growth moves along arithmetic, while Vocational High School (SMK) graduates, who are ready to enter the world of work, move along the measurement series. Thus, internship abroad must continue to be empowered, through this internship program it will slowly change the image of sending TKls who have only sent household assistants but later sending TKI graduates from Vocational High Schools (SMK), who have reliable skills so that they change from TKI. Household Assiten class becomes an expert. Meanwhile, Indramayu Regency, West Java Province, is the largest sender of Indonesian Migrant Workers (TKI) in Indonesia, reaching 4,700 people during the last 6 months of 2017. The data is based on information from BNP2TKI data collection on the total number of TKI, it turns out that the largest comes from Indramayu Regency. (Diskominfo / Media Center Indramayu / Kus). 
Even the orientation of a number of PJTKls today shows a trend of recruiting ready-to-use prospective workers with reliable skills. They do not need to report providing some kind of training education (DIKLAT) for prospective workers who will be sent abroad. No less important, the apprenticeship program must be fully supported by the local government and stakeholders, so that prospective workers in the future with qualifications for a Vocational High School (SMK) diploma will become a divisional hero who has the dignity and dignity of a decent life.

So that there will be no mistake that most of the graduates of Vocational High Schools (SMK), after finishing their studies, tend to try to find jobs that act as factory workers, employees and so on. It is rare for Vocational High School (SMK) graduates, who are willing and able to create and develop their own jobs. Vocational High Schools (SMK), are required to create not only as job providers who are ready to work in jobs that are in accordance with the needs of the business / industry, graduates of Vocational High Schools (SMK), are required to develop themselves as entrepreneurs in order to advance in entrepreneurship. with existing conditions and situations.

Vocational High Schools (SMK), with an increasing number of students and the existence of School Operational Assistance (BOS) funds, assistance from the Provincial government with an increasing number of students. In review of the Strategic Plan, Vocational High Schools (SMK), there should be more cooperation in partnering with the Business and Industry World (DUDI), through coordination meetings and team building including:

1) The school principal appoints a person who is responsible for implementing the synergy program with clear roles and responsibilities, involving school leaders such as time in the curriculum, student affairs, facilities and infrastructure and public relations and industry.

2) In formulating the infrastructure needed to achieve the goals of cooperation with the Business and Industry World (DUDI), it is not only sufficient to handle the PR and industry or involve other fields in achieving these goals, linking program objectives or activity objectives so as to form a unity. as an effort to achieve school synergy goals.

3) Adjusting the implementation of activities with free work so that staff have enough time to carry out school synergy tasks.

4) Involving all school members, allocating resources and funds by paying attention to their respective workloads in carrying out synergy programs or activities.

5) Spread knowledge from experience running synergy programs or activities and running organizational communication openly.

\section{Assessment of the Partnership between SMK and DUDI}

Assessment in the implementation of the partnership between SMK and DUDI to improve the quality of graduates who are ready to work are; (1) Formulating a company vision includes a general formulation of the purpose of existence (purpose), philosophy (philosophy), and goals (goals). (2) Develop a company profile that reflects internal conditions and capabilities. (3). Assessing the company's external environment includes competitors and general contextual factors. (4). Analyze firm choice by matching resources to external environment. (5) Identifying the most appropriate or desired option by evaluating each option based on the company's mission. (6) Selecting a set of long-term goals and a general strategy (grand strategy) that is expected to achieve the desired choice. (7) Develop annual goals and long-term strategies in accordance with the long-term goals and strategies that have been selected. (8) 
Implementing strategic choices by allocating budget resources that emphasize the suitability of tasks, human resources, structure, technology and reward systems. (9) Giving an assessment of the success of strategic processes as input for future decision makers.

As for partnerships with other business / industry (DUDI) parties, it will continue to expand networks with various parties so that the quality of graduates of vocational education institutions is superior, competitive and ready to face the current millennial developments. In the implementation of the assessment of the partnership, the assessment of learning outcomes, assessment of industrial work practice, assessment of competency tests and assessment of skills qualifications, these are usually listed in the strategic plans and work plans of educational institutions as well as quality objectives which are managed by the elements of implementing link and match partnerships with parties. the business / industrial world (DUDI), namely; PT. Teja Berlian Mitsubitshi and PT Suzuki Cinta Damai Putra Bahagia. This cooperation program has been running well or not, it is necessary to control it as a result of performance.

\section{Partnership Problems Between SMK and DUDI}

There are two problems in implementing the partnership, namely internal problems and external problems.

a. Internal problems are human resource issues managing the partnership, weak implementation of partnership cooperation, budget and infrastructure advice.

b. External problems are the problem of the number of industries that are not proportional to the number of graduates, the problem of demands from the industrial world related to fostering a good attitude at work, time discipline, diligence and honesty in addition to the skills or abilities needed by the business / industrial world (DUDI).

\section{Partnership Solution Between Vocational Schools and DUDI}

There are two solutions in implementing partnerships, namely internal solutions and external solutions:

a. Internal solutions are problems of Human Resources (HR) managing the partnership, weak implementation of partnership cooperation, budget and infrastructure advice.

1) Solutions to human resource problems in partnership managers and education personnel always require innovation and change in order to survive in a competitive business environment, make companies or organizations need great leadership, create a vision for the future, inspire members organization, and directs them to be able to achieve that vision. Leadership (leadership) is the behavior of a leader in the process of directing and influencing the behavior of subordinates. From this understanding, it is revealed that what the boss does has the spirit and excitement of work and vice versa. Human resources managing partnerships in the application of productive teachers must have real knowledge and experience obtained from the results of teacher apprenticeships in the business world and industry, can provide insight to students and be able to carry out learning in accordance with what is needed by the business world and industry. Competence in an institution education is absolutely necessary for superior human resources, especially in institutions whose existence is the center of excellence in preparing superior quality human resources.

2) The solution to the weak implementation of cooperation between Vocational Schools and Business / Industry (DUDI) educational institutions is to increase harmonious cooperation so that it can provide benefits for schools, students and the industrial world: Benefits for schools: a) Knowing information 
about the world of work that is relevant to the existing study programs in schools. b) Broaden insight about new technology. c) Industry experience for apprentice teachers. d) Industry as a source of school development. e). Increasing the skills and work experience of teachers. f) Means of distribution of labor. g). four sent pkl / internship students. h). The source of school development and its graduates. i) Possibility of assistance for practical materials, maintenance, and employee health. Benefits for students: a). Increased skills. b) Experience working as an employee. c) Character guidance information. d) Broaden horizons. Benefits for industry: a). Company promotion. b). As community service. c) Transfer of technology and information. d) Get a source of labor. e). Additional marketing areas.

3) The solution to budget problems in the implementation of the partnership program both nationally and automotive vocational educational institutions has limitations so it needs to be improved. The government's policy to increase the budget for automotive vocational education is a national relief. So the principal's efforts in overcoming the budget problem by submitting a vocational education budget from various sources that do not conflict with the provisions of financial regulations. The possibility can be sought from the school committee, especially during the implementation of apprenticeship, then school operational funds (BOS), cooperation assistance programs (training for automotive assessors) and implementation of automotive and BNSP work competency certification (PSKK), applying for CSR assistance in the industrial sector, proposing student competency alignment programs Dit PSMK and the production unit or Business Center, BKK and others need to be budgeted at the time of the preparation of the upcoming RKAS, so that the possibility of budget shortages can be resolved even though it is not yet perfect.

4) The solution to the problem of infrastructure, regarding the room for practical facilities in the production unit must meet standards for practice, practical tools are adapted to the development of the business world and the world of industry / technology development which is increasingly sophisticated. Practical facilities and competence of automotive expertise in improving partnerships in the future need the development of up-to-date practical tools and optimized use, development and arrangement of practice spaces need to get attention from school administrators. The use of productive teachers in practical facilities is very much needed and has a certificate of industrial expertise that still needs to be optimized.

b. The external solution is the problem of the number of industries that is not proportional to the number of graduates, a problem the industrial world demands.

1) The solution to the problem of the number of industries in the partnership program is the government's efforts to develop a teaching factory curriculum through a partnership between business and schools. In the curriculum, Vocational High School (SMK) students will carry out production activities according to the standards of their industrial partners. The teaching factory can develop into a Regional Public Service Agency (BLUD). So the school must continue to develop the production unit so that it is able to accommodate students who have not got a job. In every regency / city, the government opens industrial estates that can cooperate with foreign countries to increase employment in order to reduce unemployment, especially among adolescents.

2) Solution to the problem of the demands of the business world and industry on the world, because the business / industry world wants students to have the following skills to improve their quality and high selling value while entering the world of work. Like having to be good at doing business, creative, innovative, understanding the digital world (science and technology), being active in social activities, choosing the right business or choosing the right workplace with the skills you have. 
The results of this study are very important to make innovations and changes in improving the quality of graduates, as for the suggestions of researchers regarding, Management of partnerships between SMK and DUDI to improve the quality of graduates who are ready to work. This is in line with the opinion of Sudarwan Danim, that; In vocational schools, in improving the quality of graduates who are ready to work, there are several dominant factors that must be addressed (Danim, 2007. p.56), namely;

a. Principal leadership; The principal must have and understand a clear work vision, be able and willing to work hard, have a high work drive, be diligent and resilient at work, provide optimal service, and have strong work discipline.

b. Teacher; Maximum teacher involvement, by increasing the competence and professional work of teachers in seminars, workshops and training so that the results of these activities are applied in schools.

c. Students; the approach that must be taken is the child as the center so that the competence and ability of students can be explored so that schools can inventory the existing strengths of students.

d. Curriculum; the existence of a consistent, dynamic and integrated curriculum can enable and facilitate the expected quality standards so that the goals (objectives) can be maximally achieved.

e. Cooperation Network; Cooperation networks are not only limited to the school environment and the community (parents and communities) but with other organizations, such as companies or government agencies so that the output of schools can be absorbed in the world of work.

\section{Conceptual Model Offered}

Various Indonesian government policies are packaged in regulations for the realization of various kinds of policies in partnership between Vocational High Schools (SMK) and the Business and Industry World (DUDI), to improve the quality of graduates who are ready to work. This is in line with Ministerial Regulation Number 19 of 2007 which states that: Every school or madrasah establishes synergy or partnerships with other relevant institutions. Relating to input, process, output and outcome. synergy or partnership of vocational education institutions (SMA / SMK / MA / MAK) or equivalent which is carried out at least with tertiary institutions or the equivalent, the business / industry (DUDI) in their environment.

Various problems in the partnership, especially with regard to human resources (HR) managing the partnership, budget, infrastructure, the number of the Business and Industry World (DUDI), which are not comparable to Vocational High School (SMK) graduates and the demands of the industrial world, are still not yet implemented. optimal. By finding solutions and mutual agreement between leaders, managers and the world of business and industry (DUDI), is part of good performance, a network and collaboration is built so that a partnership program is created that is in line with the learning of the $21 \mathrm{st}$ century / Revolution 4.0.

This concept model focuses on the academic process of school principals in fixing human resource problems for managing partnerships, budgets and infrastructure. Because the concept of education is in improving the quality of graduates, which requires a maturation process to increase the knowledge, skills and attitudes of students, as a partnership step consisting of; planning, organizing, implementing, assessing, problems and solutions in improving the quality of graduates who are ready to work, at SMKNegeri 1 Losrang and SMN 1 Gantar seen in the partnership analysis chart as follows: 


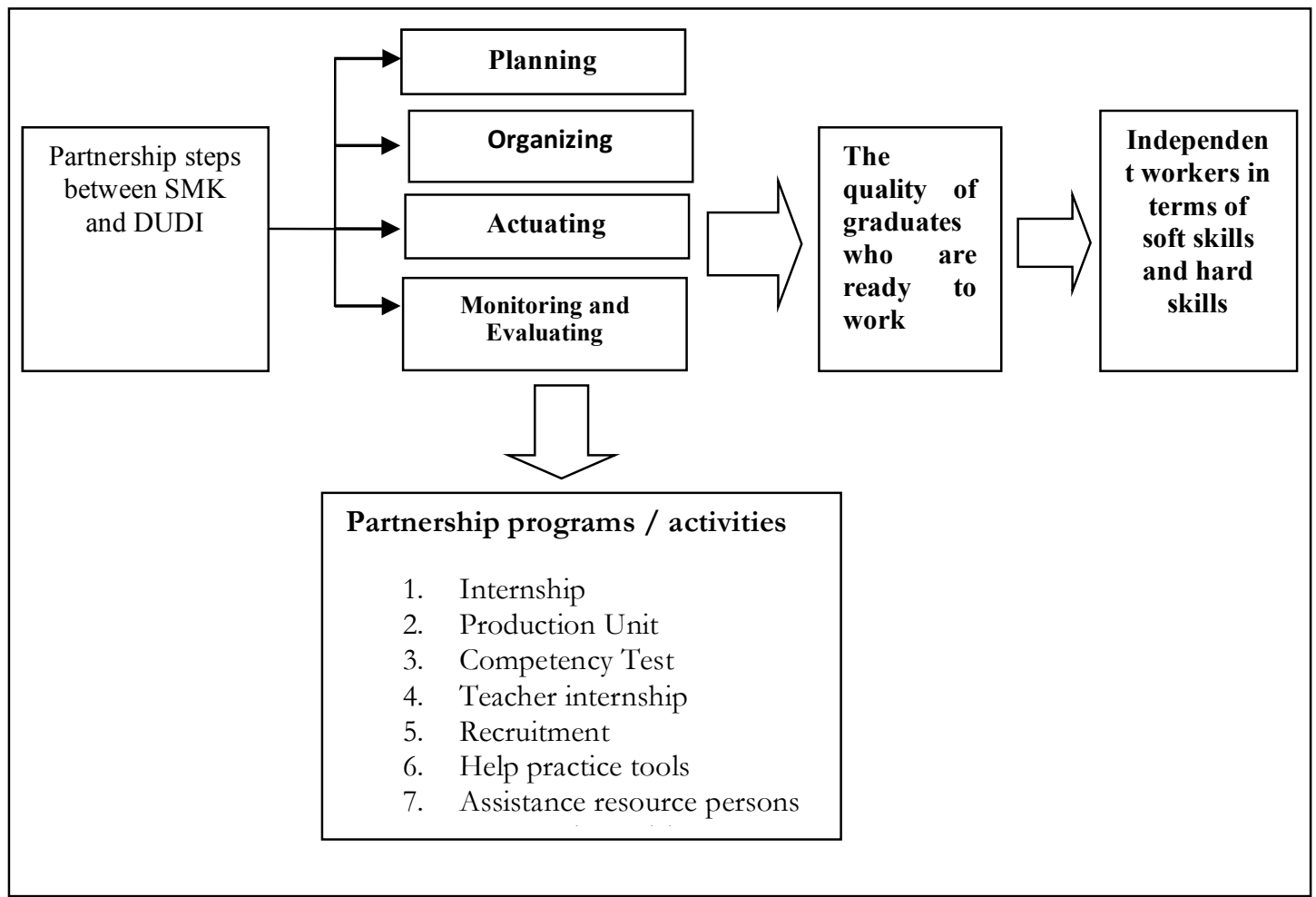

\section{Chart of the Development of the Partnership Model Concept between SMK and DUDI}

\section{CONCLUSION}

a. Partnership planning in carrying out collaboration between educational institutions with the business I industry world in improving the quality of graduates who are ready to work, planning is made with school committees, principals of vocational schools, wakasek in the field of public relations and industry, heads of light vehicle engineering programs, and teachers sit with the business / industry (DUDI) in this case PT Teja Berlian Mitsubshi and PT Suzuki Putra Damai Bahagia, so that a link and match program agreement was formed with DUDI. In planning the partnership cooperation between vocational education institutions / SMK with DUDI has long-term and short-term plans, partnership objectives, partnership benefits and partnership fields or programs as outlined in the MoU (Memorandum Of Understanding).

b. The organization that is carried out in partnership activities of Vocational High Schools (SMK) with the World of Business and Industry (DUDI) is to form a team in charge of relations with the industrial world and has its own main duties and functions. This is done so that management can work professionally and avoid concurrent positions. The principal together with the deputy head, especially the curriculum and public relations / industrial relations form the internship team and the BKK team. With the BKK is an effort to get closer to existing job opportunities with quality human resources, the Professional Certification Agency (LSP). LSP 1 is an institution established by an industry or agency with the main objective of carrying out work competency certification for the human resources of its parent institution, in accordance with the scope provided by the National Professional Certification Agency (BNSP). LSP 2 is an institution established by an industry or agency with the main objective of carrying out work competency certification for the human resources of its parent institution, human resources from its suppliers or human resources from its network, according to the scope provided by the National Professional Certification Agency (BNSP) called LSP DUDI. LSP 3 is an institution established by industrial associations and / or professional associations with the aim of carrying out work competency certification for certain sectors and / or professions according to the scope provided by the National Professional Certification Agency (BNSP), called the Professional Association LSP. 
c. The implementation of the partnership requires collaboration between PT Teja Berlian Mitshubisi and PT Suzuki Putra Peaceful Bahagia, in order to improve the quality of graduates to have a number of competencies as expected by the business world and / or the industrial world. The partnership program consists of: Industrial work practices (Prakerin), production units, competency tests (National Expertise Competency Examinations), teacher internships. recruitment, practical tools and resource person assistance.

d. There are several stages to assess the partnership between SMK and DUDI, including; assessment of learning outcomes, apprenticeship appraisal, assessment of competency package test and assessment of competency qualifications. The objective of the learning outcome assessment is to determine the absorption of the material provided in the aspects of knowledge, attitude aspects and skill aspects. While the benefits for students get knowledge from various aspects, while for the teacher to find out whether it is successful or not in the teaching and learning process. What must be assessed are several aspects including knowledge, attitude and skill aspects. Students and teachers involved in this assessment, while the implementation is usually at the end of the semester. Whereas for the internship that is involved in this assessment are students, teachers and from the industry, while the implementation is usually done at the end of the internship which is called a competency test. Followed by a certification assessment from BNSP, DUDI and the Professional Association.

e. There are several problems with the partnership between SMK and DUDI, both internally and externally. Internally, it is a matter of human resources (HR) for the management of the partnership, budget, infrastructure. While externally, the number of Businesses and Industries (DUDI), which is not comparable with the number of Vocational High School (SMK) graduates and the problem of demands from the industrial world, is still not optimal.

f. There are several solutions for the partnership between SMK and DUDI, both internally and externally. Internally, with innovation and changes in Human Resources (HR) managers, budgets and infrastructure, the government's efforts to develop a teaching factory curriculum through partnerships, and schools to prepare students to have superior competencies, be creative, innovative, understand the digital world (IPTEK) ). The future improvement step in the partnership of vocational education institutions (SMK) with the business / industry (DUDI) is to open foreign investment by the government as a step to increase the number of the Business and Industry World (DUDI) and to complete school facilities and infrastructure. This aims to increase the insight of educators, education staff and students about the quality of graduates who are ready to work with cognitive, affective, psychomotor aspects, have noble character and have good faith in accordance with the needs of the business / industrial world (DUDI).

\section{References}

Danim. (2007). Visi Baru Manajemen Sekolah. Bumi Aksara.

Jefriando, M. (2016). Pengangguran Terbesar RI Adalah Lulusan SMK. https://finance.detik.com/beritaekonomi-bisnis/d-3203625/pengangguran-terbesar-ri-adalah-lulusan-smk

Moleong, L. J. (2001). Metodologi Penelitian Kualitatif. Remaja Rosda Karya.

Mudrajad, K. (2010). Masalah, Kebijakan, dan Politik Ekonomika Pembangunan. Erlangga.

Mulyasana, D. (2011). Pendidikan Bermutu dan Berdaya Saing. Remaja Rosda Karya.

Rukmana, A. (2006). Pengelolaan Kelas dan Berbagai Faktor Yang Mempengaruhi. Remaja AECT.

Terry, G. R. (2010). Prinsip-Prinsip Manajemen. PT. Bumi Aksara.

Yin, R. K. (2011). Qualitative Research from Start to Finish. The Guilford Press. 